\title{
Is International Relations Part of the Problem or Part of the Solution?
}

\author{
Yiquan Wang ${ }^{1}$ \\ ${ }^{1}$ College of Asia and Pacific, The Australian National University, Canberra, Australia \\ Correspondence: Yiquan Wang, College of Asia and Pacific, The Australian National University, Canberra, \\ Australia. E-mail: u6270995@anu.edu.au
}

Received: October 23, 2021

Accepted: November 21, 2021

Online Published: November 23, 2021

doi:10.20849/ajsss.v6i4.953

URL: https://doi.org/10.20849/ajsss.v6i4.953

\begin{abstract}
Whether international relations are a solution to the problem or a way to provoke war is worth discussing. The Democratic Peace Theory under Liberalism holds that all democracies (or, more accurately, all liberal democracies) will not or rarely go to war with another. This theory is further explored in depth the link between democracy and peace. This paper analyzes the situation in Afghanistan, North Korea's nuclear program and the United States intervention in the world. Finally, it is concluded that international relations theory can solve regional problems and lead to conflict and war. In other words, international relations are both parts of the problem and part of the solution to the issues in international affairs.
\end{abstract}

Keywords: liberalism, democratic peace theory, Afghanistan, theory

\section{Introduction}

International Relations is a branch of political science; the research aspects range from globalization to territorial disputes, nuclear crises, human rights, etc. In the study of International Relations, most students and scholars focus on theoretical research in the discipline, linking it to the current international affairs of the world that are taking place. In the past hundred years, after four paradigm debates, three significant schools of Realism, Liberalism and Constructivism have been formed in the realm. The theory of international relations studies international relations from a theoretical point of view, and Ole R. Holist (1998) describes the theory of international relations as a pair of sunglasses that allow wearers to see only essential events related.

This paper researches the Democratic Peace Theory under Liberalism. The theory is that all democracies (or, more accurately, all liberal democracies) will not or rarely go to war with another democracy. But that doesn't mean democracies won't go to war, and it doesn't guarantee that they won't like war more than other institutions, such as some authoritarian ones (Gat 2005). This theory intensely studies have further explored the link between democracy and peace, with fewer conflicts among democracies and more occasional acts of violence on a large scale. On the contrary, increased disputes in political diplomacy (Simpson 2018). It has been used to analyze the situation in Afghanistan, the North Korean nuclear program, and American intervention in the world, concluding that international relations theory can solve regional problems and lead to conflict and war. In other words, international relations are both part of the problem and the solution to the crisis in international affairs, which requires comprehensive analysis from multiple perspectives.

\section{Literature Review}

\subsection{Theoretical Research}

\subsubsection{Liberalism}

The Enlightenment, which began in the 18th century, was a crucial ideological innovation in the history of world civilization. According to JANSEN (2016), the ideological torrents of Rationalism and human dignity have ruthlessly swept away the scum that has confined people's minds for centuries. Although enlightenment thinkers mainly discussed general philosophical issues from the perspective of individualism and Rationalism, some thinkers thought deeply about international politics and a world order based on this philosophy, which became idealism, that is, the direct source of liberal theory (Liberalism) of international relations (Konersmann 1990).

In the Enlightenment, liberal thought was represented by John Locke, Jean-Jacques Rousseau, and Kant, who established some of the basic principles of Liberalism (Walker 2008). Among these great thinkers, Kant had the most significant influence on developing the theory of international relations in later generations. In the history of 
western Liberalism, Kant's thought has played a role in the future (Walker 2008). In Western political philosophy, Kant believed that the significant losses brought about by the war between countries, the development of civil society and human rationality would eventually make the relationship between countries transition from a Hobbesian state of nature to a state of law, to achieve the goal of "permanent peace" (Babasyan 2017). McKean (2019) claimed that Kant's thought of permanent peace directly influences the development of the theory of international relations of the republic and Liberalism in later generations, that is, the Democratic Peace Theory to be discussed later.

Liberalism, which focuses on the role of rational individuals, is defined as the progressive theory of adhering to the development of international relations. The famous international relations professor Buzan (Buzan, 1993) regards Liberalism as one of the primary schools in contemporary Western international relations theory. Its formation and evolution constitute a vital part of the history of international relations. Meiser (2018) interpreted Liberalism as "liberal democracy", a defining feature of modern democracy, a way of describing free and fair elections and the rule of law, and protecting civil liberties. However, Liberalism has evolved into a distinct entity of its own when discussed in the field of International Relations theory. Liberalism embraces concepts and arguments about how institutions, behaviour, and economic ties can contain and mitigate the violent power of the state (Meiser 2018).

Meiser (2018) argued that Liberalism should be based on the moral argument that ensuring the right to life, liberty, and property of individuals is the highest goal of government. Liberals, therefore, emphasize that the well-being of the individual is an essential part of a just political system. Thus, the main point of analysis of Liberalism is to construct a system that protects individual liberty by limiting political power. Ball and Girvetz (2019) thought that the nature of these personal issues is national politics. Still, international relations is also essential to liberals because a country's activities abroad have a powerful impact on domestic freedoms. Liberals are troubled by aggressive foreign policy, and the main concern is that war requires the state to build up military power. This power can be used against foreign countries, but it can also oppress its citizens (Meiser 2018). For this reason, liberal-rooted political systems often limit military power by ensuring civilian control over the military. This gives rise to the Democratic Peace Theory of the following analysis.

\subsubsection{Democratic Peace Theory}

Democratic Peace Theory is the representative theory of liberal international security research. It argues that all countries with democratic institutions (more correctly, all liberal democracies) will not or rarely go to war with another democracy (Geis, Brock, and Müller 2007). In practice, however, the theory does not mean that democracies will not wage war; After the original version of this theory was presented, many more in-depth studies have further explored the link between democracy and peace, with fewer conflicts between democracies and less violence on a scale. One of the reasons the Democratic Peace Theory was developed relatively late was that democracies were quite rare before the end of the $19^{\text {th }}$ century. It can be traced from thought to the "permanent peace" of the German philosopher Kant during the European Enlightenment (Babasyan 2017).

Kant proposed the concept of democratic peace in his 1795 book Zum Ewigen Frieden (German), even though he had only made the Constitutional Republic one of the necessary conditions for permanent peace. According to Munn (2004), Kant's theory is that most people will never vote for war unless it is out of defence. Since the checks and balances of a republican constitution prevent risky rulers from throwing their country into battle, and every republican government obeys international law that avoids war, a constitutional republic can be a pacifist. Waltz (1962) claimed that if the declaration of war requires the consent of the citizens, there will be no war for a long time because citizens will be wary of paying the cost of war, of the devastation of the resumption of war, the heavy burden they bear. Still, the situation is different for non-republican governments. Because their rulers would not make any sacrifices for a fight, they might declare war for trivial reasons. Kant's ideas are also known as "liberal internationalism" (Munn 2004). From this perspective, International Relations is part of the problem, and democratic peace can lead to war, thus raising the refugee problem and reducing the quality of life of people.

After World War II, especially since the 1970s, with the increase in the number of democracies, many scholars have re-recognized the problem of democratic peace and gradually put this theory, systematization. In 1976, Melvin Small and J. David Singer finally responded by finding a lack of war between democracies, except for two marginal examples, but denying that the trend was statistically significant (Fukuyama and Russett 1993). After the end of the Cold War, Democratic Peace Theory has become one of the hot topics in the theory of international relations in the West. Ma-oz and Gondola (1989) extended fewer wars to fewer conflicts. Bremen (1992), Ma-oz and Russell (1992) all found that the coincidence between democracy and peace was apparent after controlling several possible research variables. Their research brings the theory of democracy and stability to the attention of mainstream academic circles. Supporters of realism in international relations and others have offered many new 
rebuttals. Other scholars have systematically studied why democracy produces peace (K-locum and choler 1995) and why democracy can influence other aspects of diplomatic relations.

In the modern international society, the standard spiritual temperament (ethos) of democracies also makes it rare for war between democracies, the fundamental characteristics of which are peaceful competition and political compromise (Griffiths 1999). According to Lynn-Jones (2019) from Harvard Kennedy School, a democratic State would envisage that other democracies would also settle disputes in a ruled and peaceful manner and apply them to external relations, so that the impression of democracies on other democracies was positive, thus making them soft and forming respectful connections. The benefits of cooperative ties between democracies will be expanded, and the expansion of such cooperation will eventually lead to a community of interests of democracies (Lynn-Jones 2019). In other words, the state will act like its adversaries, and policymakers and people will create an impression of the country from the way other leaders settle political disputes.

The norms of regular political competition, compromise to resolve political contradictions, and democracies use the peaceful transfer of rights to treat other international actors. Non-democratic countries cannot apply these norms in their external relations (Stanzel 2018). Thus, when there is a dispute of interest between two democracies, democratic norms prevent the use or threat of use of force in most conflicts. Even if they did go to war, there would be no full-scale war, so disputes between democracies and non-democracies are more likely to escalate or lead to fighting because the latter have fewer such constraints. When a democracy conflicts with a non-democratic state, it does not expect the other party to be subject to these norms but may be forced to take more robust international action than the latter to prevent itself from being exploited or eliminated (Russett and Takehiko Kamo 1996). From this point of view, International Relations is a way of solving international problems, which can be resolved in the most peaceful manner possible to save people from war to some extent.

\subsection{The Situation in International Affairs}

The disintegration of the Soviet Union and the end of the Cold War, and the U.S. becoming the sole superpower, to a large extent, caused the power and intellectual elite of the United States to fall into overconfidence of American hegemony (GOWA 2011). The soviet war in Afghanistan in 2001 and the Iraqi War in 2003 were even more so greatly enhanced this self-confidence. They believe that the U.S. has the power to dominate the world order alone and can shape the post-Cold War international system according to its own will. Gowa (2011) believed that this process of shaping is to copy the American democratic system and political model in some developing countries, and its theoretical basis is the Democratic Peace Theory as know that it-there is no war between democratic countries, so the more democratic countries, the world will be more peaceful.

When American power and political elites fell into such a myth, they seemed to have forgotten the lessons of the Vietnam War. In 1959, although the U.S. intervened on a large scale in the Vietnam War, it did not win. In the end, the U.S. failed to achieve its original strategic goals (Mcmahon 2010). According to Mcmahon (2010), in addition to the heavy financial burden, war casualties have led to a heavy domestic political responsibility. The resulting humanitarian disaster has led to criticism from the international community. The decision to withdraw from Vietnam has given the U.S. notoriety of abandoning its allies. As of August 2021, people seemed to have seen a repeat of the Vietnam War: mountain warfare was too costly but failed to eliminate the Taliban; long-distance power projection and nationalist sentiment caused by being an outsider caused the U.S. to fail to follow suit (Rescue 2021). It wanted to build an "American's Afghanistan" democratic country, and the series of burdens and problems caused by the war were surprisingly similar. Therefore, Democratic Peace Theory has some disadvantages, which pose a threat to peace and thus lead to fighting, and at the same time, due to the limitations of the theory itself, we can see that there are some disadvantages in American hegemony, led to the failure of the war in Afghanistan.

Firstly, the war in Afghanistan has shown that non-interference in the internal affairs of other countries is not only protection of small and medium-sized countries, but also a piece of advice to the great and powerful (Wood, n.d.). Even a hegemonic power like the U.S. has a hard time building a nation for Afghanistan on its own. The U.S. should not make building the Afghan state its mission. From the war on terror to calming the insurgency in Afghanistan, America's strategic goals have gradually exceeded its capabilities. It is an impossible task to build an effective and sustainable State entirely on external forces.

Secondly, some scholars believed that the U.S. has failed to promote its nation-building in response to the specific circumstances of Afghanistan but simply imposed its political system and model on Afghanistan. After the withdrawal of the Taliban, the debate in Afghanistan over whether to have a presidential or parliamentary system, a single system, or a federal system and ultimately to adopt a presidential system and a single system is 
incompatible with the political and social foundations of Afghanistan. The presidential system brings not authority and stability but a high degree of presidential corruption.

Finally, the war in Afghanistan Government (2010) shows that American hegemony itself has many problems. For example, much of the U.S. money for Afghanistan has been wasted, including, of course, corruption in the Afghan government, but also U.S. government officials and defence contractors (Sabga 2021). In Sabga's article, it shows that the hegemony itself is clearly decadent. The U.S. side of the high-profile people back to show that through the U.S., the Afghan Ministry of Security has been the "best department", can face the Taliban lonely.

On the other hand, Kiprizli and Caglar Kaya (2019) claimed that the Democratic Peace Theory had been applied in the process of adjusting the U.S. foreign strategy after the Cold War under the guise of promoting democratic peace, which can give legitimacy to the ideals and values that they believe that human beings pursue together, namely American democracy and weights, to conceal the nature of their interference in the internal affairs of other countries and the promotion of power. Lueddeke (2021) claimed that war has nothing to do with peace or democracy because it can be argued that democracy leads to more opposition to fight when the views of the population are fully expressed. However, democracy is not a "one-vote" veto system. The democracy prevailing in the world is a majority. When enough votes are cast to support a war, it is inevitable and will cause significant damage to people's lives and property.

A panel discussion from Hubert H. Humphrey Institute of Public Affairs (2008) shows that American democratic diplomacy has been characterized by interference in the internal affairs of other countries and the promotion of power politics at the beginning. In the United Nations peacekeeping operation in Somalia, the United States troops who had been remembered for spreading American democracy and values had finally withdrawn because of interference in the internal affairs of other countries; to establish a "democratic zone of peace" in Europe, the U.S. vigorously pursued the NATO eastward expansion strategy in support of new democracies in Eastern Europe, but this move was vehemently opposed by Russia (HERMANN and KEGLEY 2001); In East Asia, Wu Xinbo said that the U.S. had criticized the so-called "human rights issues" of some East Asian countries, despite the shortcomings of its human rights situation. Professor Wu Xinbo from Fudan University (2000) regards democratic diplomacy under the brand of "free democracy is the common goal of mankind", which interferes in other countries' internal affairs and hegemony more covert.

On the contrary, the doctrine of democratic peace can also bring some peaceful mediation. Lévy's (1994) point is that the Member States had achieved or expected economic reciprocity and were unwilling to wage war and thus isolate themselves. In modern times, NAFTA, APEC, and the European Union have been seen as significant incentives for this trend (Bergsten 1994). Moreover, there is a growing recognition that regional economic integration has developed faster and more rapidly than usual after the end of the Cold War. In addition, information development and social communication can bring peace. As a result of advances in science and technology and the consequence of communication, people in many countries tend to pursue the same or similar cultural and social values. Yoonhee Kang (2011) showed that the result is easier to focus on others and link other peoples' interests to their own, and easier to integrate common appeals and demands between countries and regions. For example, the anti-nuclear movement and the Greenpeace movement to protect the ecological environment, which first emerged from developed Western Europe, are now expanding more widely and deeply into most countries, forming an international force for peace and progress. Thus, Democratic Peace Theory could also serve as a solution in this regard, as a cooperative way of peacefully mediating international affairs. However, it has many controversies and limitations in the eyes of Western scholars.

\subsection{Debate and Limitation}

According to NTI (2019), many factors influence peace, world economic integration, political multiploidization, the deterrent of nuclear weapons, the United Nations, the European Union and other global or regional international organizations, the development of international law, and the development of information and the convenience of social communication channels have to some extent constrained the armed action of all countries, democratic mechanisms within countries cannot fully determine world peace. Democratic Peace Theory pursues a stable, long-term, institutionalized peace, an absolute harmony (Riker 2004). If the world's peoples still exist in the form of nation-states, contradictions, conflicts, frictions, and even violent confrontations (the highest form of which is war) must be possible.

The basic idea of Democratic Peace Theory was criticized and questioned by realists in the first place. Realists describe their theory of international order against the background of anarchy (Coetzee and Hudson 2012). In their view, competition and conflict are the essential attributes of an anarchic international community. No matter what ideology or value norm it is based on, a country can change the global political struggle with state power and 
national interests at its core (Coetzee and Hudson 2012). For the realists, the peace they recognize is only peace in some extreme state --- either peace under empire and hegemony, an island peace that is completely isolated from the world, or a temporary peace in a balance of power. Thus, anarchy and the resulting "security dilemma" make it possible for any country to "self-help" because of security needs, and peace is only relative and temporary (Hayes 2011). Although peace has always been regarded as the fundamental value and ideal pursuit of eastern political science, it cannot be interpreted as non-war. In other words, according to Hayes (2011), in the international system composed of nation-States, the pursuit of national interests remains the central theme of international politics, and even if there is no hostile act or resort to force between States, the purpose of national interests of a State may still pose a threat to other states, leaving them in a "state of war".

\section{Theoretical Analysis and Case Study}

\subsection{Liberalism and Democratic Peace Theory}

Before it became a political philosophy, Liberalism was not so difficult to define. Simply put, Liberalism is a liberal and generous person who is a little fat, just as liberal, but a little fat people may not be appreciated. Still, few people feel that they are dangerous to the country (BARÇADURMUŞ 2018). In the context of the time, the antonym of Liberalism was not conservatism but strict. Many years later, it became a political term: Liberalism. The first substantial appearance of the word was in Spain during Napoleon's occupation (DWYER 2010). Although it has become synonymous with political leftists, it has many definitional troubles at the earliest. Liberalists are not arguing with others on academic lists and methods. They understand that conflicts are inevitable. They do not trust unfair authority, believe in progress, and respect everything, at least many people (DWYER 2010). It is more like a way of engaging in political activities than a fixed political position.

In China, Liberalism and Confucianism have similarities. In the 1990s, the renewed Liberalism in mainland China adopted a friendly attitude towards tradition emotionally and intellectually (Cheng 2008). This conservative turn has caused widespread controversy within the liberal ideological circle and attracted the attention of other schools of thought, such as the conservatism that seeks to revive Confucianism, thereby changing the pedigree of contemporary Chinese thought to a certain extent. The conservative turn of Liberalism began in the 1950s. Still, it occurred in Taiwan, which was isolated from mainland China and was seldom known by the mainland academic circles on a closed island (Wang 1998). The conceptual origin of the anti-traditional attitude of modern Chinese liberals is the internal logic of the type of liberal ideology they have believed. The philosophical basis of this ideology is "Rationalism" (Segal 1999). In a nutshell, what modern Chinese liberals pursue is establishing a constitutional system in China to protect human freedom and rights. Such a system can be understood as a set of rules permeating free values and having complex interrelationships. Thus, the cause of establishing a free constitutional government is to establish such a system of rules that can function effectively in China (Luo 2021).

The Democratic Peace Theory under Liberalism is also seen by Kant as a tool of Rationalism, arguing that most people will never vote for war unless it is for defence (Luo 2021). Because the checks and balances of republican constitutions prevent dangerous rulers from plunging their countries into battle, and because every republican government abides by international law to avoid war, constitutional republics can be pacifists (Hunter 1988). Also, the Democratic Peace Theory has been a controversial issue in Western academia in recent years. From a purely theoretical point of view, its current development is closely related to exploring the phenomenon of "Long Peace" by Western scholars in Post-World War II Europe and the world after the end of the Cold War (Acharya 2014).

In addition, Liberalism has permanently attached importance to the influence of domestic factors on international relations, which are closely related to the development of interdependence and the growth of "non-power factors" (Kaya and Kirrily 2019). The theory of democratic peace emphasizes the role of national checks and balances such as individual domestic expression, political freedom, and democratic mechanism. It advocates that the degree of domestic political freedom can affect international politics and attempts to push Liberalism from domestic politics to international politics to cause a massive role in the global process (Place 2012).

\subsection{Democratic Peace Theory: Solution or Problem?}

Some scholars believe there is no war between democracies, just like the rule of thumb in international relations. This view challenges the realistic view prevailing in international relations, emphasizing the calculation of the balance of power and the shared strategic interests to explain peace and stability, characteristic of relations between free democracies (Place 2012). Therefore, if democracy spreads in the world coincides with economic interdependence and the strengthening of international organizations, it will bring about greater international peace. The theory of international relations preserves world peace and brings a peaceful solution to international affairs. 
In the two main branches of Democratic Peace Theory, the structural explanation holds that representative government institutions make elected officials and policymakers accountable to a broad electorate and make war unattractive primarily to governments and citizens (Russet 2009). Since the costs and risks of war directly affect large parts of the population, it is expected that ordinary voters will lose their jobs if the current leader or party launches a failed or unnecessary war (Russet 2009). So even if there is a non-liberal leader, institutions such as freedom of speech, political pluralism, and competitive elections will make it difficult for those leaders to persuade or persuade the public to go to war. By contrast, proponents of the normative or cultural view argue that shared democratic and liberal values best explain the peace between democracies (Fendi us Elman 1997). According to this view, the democratic political culture encourages peaceful conflict resolution that has spread beyond domestic political processes to other democracies. Leaders in both countries have reason to expect that their counterparts will also resolve their differences peacefully (John Owen, n.d.).

Although some scholars believe that structural and normative explanations are mutually exclusive, the defence of democratic peace theory is more intuitive and persuasive by combining the two viewpoints (Mao 1997). The two reasons are complementary in that cultural norms influence the creation and evolution of political institutions. Institutions help produce a more peaceful moral culture over time, so international relations theory becomes part of the solution. However, this undermines primarily by a raft of research showing that democracies are extremely unlikely to fight each other, regardless of the definition of democracy, the type of case considered or the threshold of war (Mao 1997).

While not questioning empirical findings, substantive criticism argues the causal relationship between democracy and peace. Realists say that common interests, not standard regimes, best explain the low incidence of war among democracies (Farber and Gowan 1995). The structure of the international political system is a critical factor in determining how countries act, and two non-democracies with common interests are more likely to fight each other than two democracies with no common interests. Critics of Democratic Peace Theory are right that liberal democracies are not significantly less likely to go to war with other non-democracies (Mao 1997). Available evidence essentially refutes the monism that democracies find it difficult to use force, regardless of the type of regime in the opposing state. Power politics remains a necessary reality for most democracies, especially given the high level of conflict between the mixed dyads (Patayan 2012). Thus, the Democratic Peace Theory has become a global problem under such circumstances, leading to war.

\subsection{Case Study: Situation in Afghanistan}

Some Western countries, led by the United States, have long held the right to speak on democratic issues. However, America's self-proclaimed democratic model is increasingly questioned, both domestically and internationally. From the domestic point of view of the United States, the chaos caused by the fall of "American democracy" has been seen by the outside world, the disorder of democratic systems caused by political chaos, further tearing up American society (Ralph 2001).

Similarly, in dealing with international relations and affairs, the U.S. has left democratic principles behind and pursued the direction of anti-democratic hegemony that the U.S. must dominate (Kim 2012). The most striking example is the interference in the internal affairs of other countries through the implementation of "long-arm jurisdiction", that is, the intervention of the Eastern and Western countries (Cerna 1995). This unequal inter-state relationship is reflected in the relationship between the U.S. and developing countries and between the U.S. and its allies. The idea of classifying countries into three or six ranks directly contradicts the principle of sovereign equality of states enshrined in the UN Charter (U.N. 2021).

In the relationship with other international multilateral institutions and international organizations, the U.S. is also selfish attitude. The Trump government pulled out of U.N. education, scientific, and cultural organizations from the Paris Agreement on climate change, withdrew from the world health organization, and even investigated the Afghanistan war crimes by the international criminal court sanctions without a word (Cyr 2013). During the COVID-19 pandemic, the U.S. also put national interests first and implemented isolationism and unilateralism. It was wielding the big stick of sanctions, bullying, and threats to international institutions. It finally became the biggest troublemaker for global security and stability.

On August 30, 2021, the U.S. announced that it had completed its withdrawal from Afghanistan, ending nearly two decades of U.S. military operations in the country (Macias 2021). A little review of history makes it easy to see that over the past 20 years, the U.S. has glorified acts of aggression, killing and pillage at home and abroad in the name of "democracy". In April 2021, U.S. President Joe Biden announced that the U.S. had completed its mission to combat terrorists and would withdraw all U.S. troops from Afghanistan by September 11 to end the longest war the U.S. has ever experienced on foreign soil (Macias 2021). Biden acknowledged that even after nearly two decades of war, the U.S. could not turn Afghanistan into a modern and stable country. 
For 20 years, there has been no dawn of peace in Afghanistan. Although the U.S. drove out the Taliban and eliminated Bin Laden, the number of terrorist organizations did not decrease but increased from a position to more than 20 (Walt 2002). The U.S. invaded and occupied Afghanistan for 20 years in the name of counterterrorism, not for the just cause of counterterrorism, but for so-called hegemony. According to the latest 2021 statistics, $36 \%$ of the African population lives below the poverty line. The number of poor people in Afghanistan has soared to 47.3\% by 2020, with the U.S. occupation making half of the population refugees (Sajjad 2021). Moreover, Americans do not care whether Afghans are rich or poor, healthy or weak. Their prize is the land of Afghanistan, the central transport hub in the heart of Asia, buried in a treasure trove of immense value.

In the guise of promoting democracy and peace, they can cover up American democracy and values, which they believe are the common ideals and values pursued by human beings, with a legitimate cloak to cover up its nature of interfering in other countries internal affairs power. Specifically, the Post-Cold War American "democratic diplomacy" has three characteristics.

Primarily, expand the political system and values of the U.S. through free and democratic ideals, and make democratic diplomacy an essential part of American power (Fabry 2009). The U.S. government believes that American values of individual freedom and tolerance are specific manifestations of democracy and emphasizes that national security must expand a market democratic society and contain threats to the interests of the United States and its Allies. Protecting and strengthening American values is the goal of its security strategy (J. ABRAMOWITZ 2021). On the other hand, the U.S. government believes that it must lead the world towards freedom and democracy and that democratic diplomacy should be regarded as an essential means.

Posteriorly, democratic diplomacy in the U.S. has been characterized from the beginning by interference in the internal affairs of other countries and the promotion of power politics (Daalder and Lindsay 2003). American soldiers in U.N. peacekeeping operations, remembered for spreading American democracy and values, eventually withdrew from Somalia due to interference in other countries internal affairs. To create a "zone of democratic peace" in Europe, the United States vigorously promoted the eastward expansion of NATO. It supported the "new democracies" in Eastern Europe, but Russia strongly opposed this (Karkovic 1995). In East Asia, the United States has criticized the so-called "human rights issues" of some East Asian countries, especially China, despite its dire human rights situation (Waal 2021). The AUKUS Alliance recently formed, and Australia's allies consider it a positive development for democracy, peace, and prosperity (Zhu 2021). This alliance is, even more, disregarding the norms of international law and blatantly pursuing the maritime hegemonism of power politics. Democratic diplomacy under the brand of "free democracy is the common goal of mankind" interferes in other countries internal affairs and hegemony more covert (Carta 2017).

Thirdly, American democratic diplomacy remains strongly ideological. Although the ideological struggle in post-Cold War international relations has been weakened, it does not mean that Western diplomacy has been rid of the influence of ideological factors but has a new focus on the object. The current ideological struggle is not only a struggle between communism and capitalism but even a struggle between different "civilizations" (Hedin 2004). After the Soviet and Eastern socialist systems disintegrated, the western powers in the ideological offensive were more prosperous. They aim to force "transformation" in all countries that do not practise Western democracy (Opedal, Rommetvedt, and Vrangbaek 2011). In essence, certain norms in this ideology are often used to achieve specific political goals and exert political influence.

The Democratic Peace Theory needs to be applied in different aspects. If the characteristics of a peaceful and negotiated settlement are taken advantage of, it will become a solution. However, the U.S. uses it to intervene in other countries politics and exercise hegemony under the banner of democracy. In this case, Democratic Peace Theory has become a significant international issue, and many scholars have criticized it. In fact, since the beginning of the 21 st century, the application of democratic peace theory has failed. The withdrawal of the U.S. from Afghanistan also represents the failure of a kind of democratic hegemony and reflects the limitations of Democratic Peace Theory.

In addition to the Democratic Peace Theory under Liberalism, realism can also prove the above view. From the perspective of realism, the long-term inability of the DPRK and the U.S. to communicate directly and distrust each other has led to a "security dilemma" between the two countries, leading to the development of nuclear weapons by the DPRK (Gardels 2017). To get rid of the current "security dilemma", the key is whether the DPRK and the U.S. can transcend the realistic perspective, give up their hostility to each other, and finally build a truly peaceful and stable security community in Northeast Asia.

Realists believe that countries in the international system are the same as people in society, so countries in the global system must also rely on power to ensure their security and pursue national interests (Kim 2018). In the bipolar structure of the Cold War, because the U.S. and the Soviet Union were superpowers, other countries were 
forced to join the two camps. Realists believe that this bipolar pattern is relatively stable and that wars occur naturally and cannot be avoided. However, some systems (such as the bipolar pattern system) are relatively stable and generally are not prone to wear. From a realist perspective, China and North Korea protect their status and security (Kim 2018).

From the perspective of the U.S., the North Korean nuclear program that changes the balance of political and military power in East Asia conflicts with America's regional interests. The dominant country can tolerate small or even partial changes to the balance of power. Still, countries with vested interests will inevitably oppose any attempt to completely disrupt the established international political order (Graham 2021). After 2002, some incidents severely affected the peace and stability of Northeast Asia, such as North Korea's withdrawal from the Nuclear Non-Proliferation Treaty and North Korea's nuclear explosion (Graham 2021). The reality has brought the U.S. back to the path of realism.

\section{Conclusion}

Today's international community is a complex and diverse global system. In the face of the diversity of the international community and the differences in understanding of democracy among countries, countries should respect each other's right to choose their social system and development path, embrace various ideas based on the values of equality and openness, resolve contradictions and conflicts through democratic consultation and build a civilization of peaceful coexistence. Whether international relations are a solution or a problem depends on applying theories related to international relations. Any idea has one side of a peaceful solution and the other side of the issues that cause global wars.

\section{References}

Abramowitz, J. M. (2021). Diplomacy and Democracy: Putting Values into Practice. Retrieved from https://afsa.org/diplomacy-and-democracy-putting-values-practice

Acharya, A. (2014). Global International Relations (I.R.) and Regional Worlds. International Studies Quarterly, 58(4), 647-59. https://doi.org/10.1111/isqu.12171

Babasyan, T. (2017). Permanent Peace amid the Warlike World. European Scientific Journal, ESJ, 13(13), 114. https://doi.org/10.19044/esj.2017.v13n13p114

Ball, T., \& Girvetz, H. K. (2019). Liberalism | Definition, History, \& Facts. In Encyclopaedia Britannica. Retrieved from https://www.britannica.com/topic/liberalism

Barçadurmuş, F. (2018). Deep History of Liberalism: An Approach to Liberalism History. Journal of Awareness, 3(3), 1-10. https://doi.org/10.26809/joa.2018342288

Bergsten, C. F. (1994). APEC and World Trade: A Force for Worldwide Liberalization. Foreign Affairs, 73(3), 20. https://doi.org/10.2307/20046655

Buzan, B. (1993). From International System to International Society: Structural Realism and Regime Theory Meet the English School. International Organization, 47(3), 327-52. https://doi.org/10.1017/s0020818300027983

Carta, M. (2017). What Is Democracy? - Rights. Web-Archive-2017. Retrieved from https://web-archive-2017.ait.org.tw/infousa/zhtw/DOCS/whatsdem/whatdm3.htm

Cerna, C. M. (1995). Hugo Princzv. Federal Republic of Germany: How Far Does the Long-Arm Jurisdiction of U.S. Law Reach?. Leiden Journal of International Law, 8(2), 377-93. https://doi.org/10.1017/s0922156500003381

Cheng, Y-H. (2008). Liberalism in Contemporary China: Ten Years after Its 'Resurface.' Journal of Contemporary China, 17(55), 383-400. https://doi.org/10.1080/10670560701809619

Coetzee, E., \& Hudson, H. (2012). Democratic Peace Theory and the Realist-Liberal Dichotomy: The Promise of Neoclassical Realism?. Politikon, 39(2), 257-77. https://doi.org/10.1080/02589346.2012.683942

Cyr, A. I. (2013). Little America: The War within the War for Afghanistan. The RUSI Journal, 158(2), 107-8. https://doi.org/10.1080/03071847.2013.787745

Daalder, I. H., \& Lindsay, J. M. (2003). The Globalization of Politics: American Foreign Policy for a New Century. Brookings. Retrieved from https://www.brookings.edu/articles/the-globalization-of-politics-american-foreign-policy-for-a-new-century/

Dwyer, P. (2010). Napoleon and the Universal Monarchy. History, 95(319), 293-307. https://doi.org/10.1111/j.1468-229x.2010.00487.x 
Fabry, M. (2009). The Inter-American Democratic Charter and Governmental Legitimacy in the International Relations of the Western Hemisphere. Diplomacy \& Statecraft, 20(1), 107-35. https://doi.org/10.1080/09592290902813239

Farber, H. S., \& Gowa, J. (1995). Polities and Peace. International Security, 20(2), 123. https://doi.org/10.2307/2539231

Fendi, E. M. (1997). The Need for a Qualitative Test of the Democratic Peace Theory. In Paths to Peace: Is Democracy the Answer? (pp. 11-12). Cambridge, Massachusetts: The MIT Press.

Fukuyama, F., \& Russett, B. (1993). Grasping the Democratic Peace: Principles for a Post-Cold War World. Foreign Affairs, 72(5), 157. https://doi.org/10.2307/20045825

Gardels, N. (2017). A New Urgent Realism Is Making Negotiations with North Korea More Likely. New Perspectives Quarterly, 34(3), 6-9. https://doi.org/10.1111/npqu.12085

Gat, A. (2005). The Democratic Peace Theory Reframed: The Impact of Modernity. World Politics, 58(1), 73-100. https://doi.org/10.1353/wp.2006.0017

Geis, A., Brock, L., \& Müller, H. (2007). From Democratic Peace to Democratic War?. Peace Review, 19(2), 157-63. https://doi.org/10.1080/10402650701353570

Government, Afghanistan. (2010). What We Need to Learn: Lessons From Twenty Years of Afghanistan Reconstruction. Retrieved from https://www.sigar.mil/pdf/lessonslearned/SIGAR-21-46-LL.pdf

Gowa, J. (2011). The Democratic Peace After the Cold War. Economics \& Politics, 23(2), 153-71. https://doi.org/10.1111/j.1468-0343.2011.00382.x

Graham, A. T. (2021, May). The Nuclear Non-Proliferation Treaty: Delayed Review - Issues Old and New. Journal for Peace and Nuclear Disarmament, 1-10. https://doi.org/10.1080/25751654.2021.1921499

Griffiths, S. (1999). Democracy and Deep-Rooted Conflict. Civil Wars, 2(2), 111-16. https://doi.org/10.1080/13698249908402409

Hayes, J. (2011). The Democratic Peace and the New Evolution of an Old Idea. European Journal of International Relations, 18(4), 767-91. https://doi.org/10.1177/1354066111405859

Hedin, A. (2004). Stalinism as a Civilization: New Perspectives on Communist Regimes. Political Studies Review, 2(2), 166-84. https://doi.org/10.1111/j.1478-9299.2004.00006.x

Hermann, M. G., \& Kegley, C. W. (2001). Democracies and Intervention: Is There a Danger Zone in the Democratic Peace?. Journal of Peace Research, 38(2), 237-45. https://doi.org/10.1177/0022343301038002007

Holsti, K. J. (1998). Scholarship in an Era of Anxiety: The Study of International Politics during the Cold War. Review of International Studies, 24(5), 17-46. https://doi.org/10.1017/s0260210598000175

Hubert, H., \& Humphrey Institute of Public Affairs. (2018). Diplomacy and Democracy. The American Academy of Diplomacy. Retrieved April 28, 2018, from https://www.academyofdiplomacy.org/program/diplomacy-and-democracy/

Hunter, G. (1988). Liberalism, Kant, Pox: A Reply to Rolf George. Dialogue, 27(2), 211-14. https://doi.org/10.1017/s0012217300019739

Jansen, H. (2016). In Search Of New Times: Temporality in the Enlightenment and Counter-Enlightenment. History and Theory, 55(1), 66-90. https://doi.org/10.1111/hith.10788

John, O. n.d. How Liberalism Produces Democratic Peace.

Kacowicz, A. M. (1995). Explaining Zones of Peace: Democracies as Satisfied Powers?. Journal of Peace Research, 32(3), 265-76. https://doi.org/10.1177/0022343395032003002

Kang, Y-H. (2011). Anti-Nuclear Movement in Post-Soviet Russia: Focusing on Nuclear Industry. 러시아연구, 21(2), 181-213. https://doi.org/10.22414/rusins.2011.21.2.181

Kaya, Y. C., \& Kiprizli, G. (2019). Does Democratic Peace Theory Genuinely Envision Global Peace? A Critical Approach. Journal International Studies, 15. https://doi.org/10.32890/jis2019.15.5

Kim, E. (2018, April). The Sino-DPRK Split and Origins of US-DPRK Bilateralism. European Journal of Korean Studies, 73-84. https://doi.org/10.33526/ejks.20181702.73

Kim, M.-H. (2016). South Koreas Strategy toward a Rising China, Security Dynamics in East Asia, and International Relations Theory. Asian Survey, 56(4), 707-30. https://doi.org/10.1525/as.2016.56.4.707 
Kim, S-B. (2012). Standard Competition as a Hegemony Competition in World Politics : U.S. Hegemony, Japan's Frustration, and China's Challenge. Asia Review, 2(2), 95. https://doi.org/10.24987/snuacar.2012.12.2.2.95

Kiprizli, G., \& Kaya, Y. C. (2019, December). Does Democratic Peace Theory Genuinely Envision Global Peace? A Critical Approach. Journal of International Studies. https://doi.org/10.32890/jis.15.2019.8027

Konersmann, R. (1990). Idealism and Enlightenment. Continuity and Criticism of the Enlightenment in Philosophy and Literature around 1800. Philosophy and History, 23(2), 129-30. https://doi.org/10.5840/philhist199023262

Lévy, B. (1994). The European Union and NAFTA: Two Regional Economic Blocs in a Complex Globalized and Interdependent International Economy. Journal of European Integration, 17(2-3), 211-33. https://doi.org/10.1080/07036339408429005

Lueddeke, G. (2021). War and Peace?. Impakter. Retrieved August 28, 2021, from https://impakter.com/war-peace-armed-conflicts-rise-democracy-declines/

Luo, S. S. (2021, September). The Liberalism of Fear in China: Hu Ping and the Uses of Fear and Memory in Contemporary Chinese Liberalism. Global Intellectual History, 1-19. https://doi.org/10.1080/23801883.2021.1977674

Lynn-Jones, S. M. (2019). Why the United States Should Spread Democracy. Belfer Center for Science and International Affairs. Retrieved from https://www.belfercenter.org/publication/why-united-states-should-spread-democracy

Macias, A. (2021). U.S. Ends 20-Year War in Afghanistan with Final Evacuation Flights out of Kabul. CNBC. Retrieved August 30, 2021, from https://www.cnbc.com/2021/08/30/afghanistan-update-last-us-troops-leave-kabul-ending-evacuation.html

Maoz, Z. (1997). The Controversy over the Democratic Peace: Rearguard Action or Cracks in the Wall? International Security, 22(1), 162-98. https://doi.org/10.1162/isec.22.1.162

McKay, S. (2012). A Long Goodbye to Bismarck? The Politics of Welfare Reform in Continental Europe Edited by Bruno Palier. Social Policy \& Administration, 46(1), 129-31. https://doi.org/10.1111/j.1467-9515.2011.00821.x

McKean, B. L. (2019, August). Kant, Coercion, and the Legitimation of Inequality. Critical Review of International Social and Political Philosophy, 1-23. https://doi.org/10.1080/13698230.2019.1658481

Mcmahon, R. J. (2010). Remembering, and Forgetting, the Vietnam War. Diplomatic History, 35(1), 163-69. https://doi.org/10.1111/j.1467-7709.2010.00942.x

Meiser, Jeffrey W. (2018). Introducing Liberalism in International Relations Theory. E-International Relations. Retrieved February 18, 2018, from https://www.e-ir.info/2018/02/18/introducing-liberalism-in-international-relations-theory/

Munn, J. (2004). Kant and Liberal Internationalism. Canadian Journal of Political Science, 37(4), 1063-64. https://doi.org/10.1017/s0008423904460211

NTI. (2019). Live Tweeting Nuclear War: Social Media, WMD Threats, and Crisis Communication | NTI. Retrieved October 15, 2019, from https://www.nti.org/analysis/atomic-pulse/live-tweeting-nuclear-war-social-media-wmd-threats-and-crisis-c ommunication/

Opedal, S., Rommetvedt, H., \& Vrangbaek, K. (2011). Organized Interests, Authority Structures and Political Influence: Danish and Norwegian Patient Groups Compared. Scandinavian Political Studies, 35(1), 1-21. https://doi.org/10.1111/j.1467-9477.2011.00274.x

Patapan, H. (2012). Democratic International Relations: Montesquieu and the Theoretical Foundations of Democratic Peace Theory. Australian Journal of International Affairs, 66(3), 313-29. https://doi.org/10.1080/10357718.2012.672951

Placek, K. (2012). The Democratic Peace Theory. E-International Relations. Retrieved from https://www.e-ir.info/2012/02/18/the-democratic-peace-theory/

Ralph, J. (2001). American Democracy and Democracy Promotion. International Affairs, 77(1), 129-40. https://doi.org/10.1111/1468-2346.00182 
Rescue. (2021). Afghanistan Crisis: Latest Updates, Ways to Help. International Rescue Committee (IRC). $\begin{array}{llll}\text { Retrieved } \quad \text { September } & \text { 2021, from }\end{array}$ https://www.rescue.org/article/afghanistan-crisis-latest-updates-ways-help

Riker, W. (2004). Rawls's Decent Peoples and the Democratic Peace Thesis. Social Philosophy Today, 20, 137-53. https://doi.org/10.5840/socphiltoday20042016

Russett, B. M. (2009. Democracy, War and Expansion through Historical Lenses. European Journal of International Relations, 15(1), 9-36. https://doi.org/10.1177/1354066108100051

Russett, B. M., \& Kamo, T. (1996). Grasping the Democratic Peace: Principles for a Post-Cold War World. Tōkyō: Tōkyō Daigaku Shuppankai.

Sabga, P. (2021). The U.S. Spent \$2 Trillion in Afghanistan - and for What?. Retrieved August 16, 2021, from https://www.aljazeera.com/economy/2021/8/16/the-us-spent-2-trillion-in-afghanistan-and-for-what

Sajjad, T. (2021). Where Do Afghanistan's Refugees Go?. The Conversation. Retrieved September 1, 2021, from https://theconversation.com/where-do-afghanistans-refugees-go-166316

Segal, S. (1999). The Relationship between the Nationalism of One Nation and the Rationalism of Liberalism. Journal of Australian Studies, 23(60), 160-67. https://doi.org/10.1080/14443059909387463

Simpson, S. (2018, December). Making Liberal Use of Kant? Democratic Peace Theory and Perpetual Peace. International Relations, 004711781881146. https://doi.org/10.1177/0047117818811463

Stanzel, V. (2018). New Realities in Foreign Affairs: Diplomacy in the 21st Century. Stiftung Wissenschaft Und Politik $\quad(S W P) . \quad$ Retrieved November 12, 2018, from https://www.swp-berlin.org/en/publication/new-realities-in-foreign-affairs-diplomacy-in-the-21st-century

U.N. (2021). Repertory of Practice of United Nations Organs - Codification Division Publications. Retrieved March 10, 2021, from https://legal.un.org/repertory/art2.shtml

Waal, E. B., Corre, P. L., Stronski, P., \& de, T. (2021). China's Influence in Southeastern, Central, and Eastern Europe: Vulnerabilities and Resilience in Four Countries. Carnegie Endowment for International Peace. Retrieved October 13, 2021, from https://carnegieendowment.org/2021/10/13/china-s-influence-in-southeastern-central-and-eastern-europe-vu lnerabilities-and-resilience-in-four-countries-pub-85415

Walker, T. C. (2008). Two Faces of Liberalism: Kant, Paine, and the Question of Intervention. International Studies Quarterly, 52(3), 449-68. https://doi.org/10.1111/j.1468-2478.2008.00510.x

Walt, S. M. (2002). Beyond Bin Laden: Reshaping U.S. Foreign Policy. International Security, 26(3), 56-78. https://doi.org/10.1162/016228801753399718

Waltz, K. N. (1962). Kant, Liberalism, and War. American Political Science Review, 56(2), 331-40. https://doi.org/10.2307/1952369

Wang, A. (1998). Taiwan and Social Liberalism: Doomed Marriage or Match Made in Heaven?. The Washington Quarterly, 21(4), 13-16. https://doi.org/10.1080/01636609809550347

Wood, M. n.d. Non-Intervention (Non-Interference in Domestic Affairs). The Princeton Encyclopedia of Self-Determination. Retrieved from https://pesd.princeton.edu/node/551.

Wu, X-B. (2000). U.S. Security Policy in Asia: Implications for China-U.S. Relations. Brookings. Retrieved September 1 , 2000, from https://www.brookings.edu/research/u-s-security-policy-in-asia-implications-for-china-u-s-relations/

Zhu, M. (2021). What Is the Aukus Alliance, and What Does It Have to Do with China?. South China Morning Post. Retrieved October 10, 2021, from https://www.scmp.com/news/china/diplomacy/article/3151700/aukus-alliance-what-it-what-does-it-have-do -china-and-why

\section{Copyrights}

Copyright for this article is retained by the author(s), with first publication rights granted to the journal.

This is an open-access article distributed under the terms and conditions of the Creative Commons Attribution license (http://creativecommons.org/licenses/by/4.0/). 